\title{
An Analysis of Reinsurance and Firm Performance: Evidence from the Taiwan Property-Liability Insurance Industry
}

\author{
Hsu-Hua Lee and Chen-Ying Lee \\ Graduate Institute of Management Sciences, No. 151, Yíngzhuan Rd., Tamsui Dist., New Taipei City, 886 \\ Taiwan R.O.C. \\ E-mail: chenying0207@yahoo.com.tw
}

This study investigates the relationship between reinsurance and firm performance by sourcing panel data from the 1999 to 2009 period of the property-liability insurance industry in Taiwan. The results of this investigation offer some insight that firm performance and reinsurance are interdependent. We find that insurers with higher return on assets (ROA) tend to purchase less reinsurance and insurers with higher reinsurance dependence tend to have a lower level of firm performance. Therefore, managers have to strike a balance between decreasing insolvency risk and reducing potential profitability. Other empirical results show that ROA, underwriting risks, liquidity ratio, business line concentration, return on investment (ROI) and financial holding dummy have a significant correlation with reinsurance. In addition, firm size, financial leverage, reinsurance, underwriting risks, liquidity ratio and ROI have a significant influence on firm performance. Our results have practical implications for the property-liability insurance industry and competent authorities in Taiwan.

The Geneva Papers (2012) 37, 467-484. doi:10.1057/gpp.2012.9

published online 18 April 2012

Keywords: reinsurance; property-liability insurance; panel data; firm performance

\section{Introduction}

The insurance industry in Taiwan has seen gradual growth in revenue along with the development of finance and the economy. The assets of the Taiwanese insurance industry accounted for approximately 23.53 per cent of all financial institutions in 2009. Recently, insurance companies have been focusing on the cash-flow underwriting approach, as they are using price competition to aim for a higher market share. Thus, a number of property-liability insurance companies have become insolvent and have withdrawn from the market. ${ }^{1}$ The above business model can survive a stable economy. However, during periods of recession (e.g. in the event of a global financial

\footnotetext{
${ }^{1}$ In 2005, Kuo Hua Insurance Co., Ltd. ceased operations and went out of business. In 2009, Walsun Insurance Co., Ltd. failed to fulfil its contractual obligations to its policyholders. Its capital adequacy ratio fell below the required standard and the financial situation deteriorated significantly. Eventually it ceased operations.
} 
crisis), insurance companies would suffer losses in underwriting profits and investment returns. Any negligence of risk management could undermine the firm value, affect shareholders' rights or even cause companies to become insolvent. Hancock et al. ${ }^{2}$ indicated that in a changing environment guiding principles need to be revisited. For the property-liability insurance industry, this means that to return to past levels of profitability, it is necessary once again to reflect on the underlying mechanism of value creation.

Calandro and $\mathrm{Scott}^{3}$ claim that reinsurance usage should be added to the list of factors influencing insurer performance. Insurers frequently manage risk by purchasing reinsurance because it reduces bankruptcy risk, expanding capacity, stabilisation of loss experience and catastrophe protection. Reinsurance activities may increase cost, leading to higher prices and/or lower profits. Thus, reinsurance transactions are related to underwriting risk and capacity, and affect ceding insurers' performance and conduct. In addition, the reinsurance literature has suggested that firms that are more profitable should be better able to absorb large unexpected losses and therefore use less reinsurance. ${ }^{4}$ Therefore, the insurer's performance will also affect reinsurance decisions. The reinsurance ratio of the property-liability insurance industry in Taiwan is overly high. Over the last 11 years $(1999 \sim 2009)$, the Taiwan market reinsurance ratio has been 41.97 per cent, ${ }^{5}$ which is much higher than the world average of $20 \sim 25$ per cent. As the scale is limited in Taiwan and there are catastrophe risk exposures, the property-liability industry relies on the support of reinsurance. Thus, the purchase of reinsurance is important to the performance of the Taiwanese property-liability insurance industry. It is imperative for the industry to explore ways of adjusting reinsurance strategies and focus on business quality and underwriting profitability. A better reinsurance decision can create value for insurance companies, in order to brace for any potential financial crisis.

This study investigates the relationship between reinsurance decisions and the insurer's performance. According to the previous literature, firm performance can be measured using financial ratios analysis and an analysis of input and output factors. For example, Data Envelopment Analysis is the most frequently applied method of frontier efficiency analysis in insurance. ${ }^{6}$ Differing from previous insurance performance research, this study is the first research using panel data on a sample of Taiwan property-liability insurers to simultaneously examine the impact of firm performance on reinsurance and the reverse causation from reinsurance to firm performance. Prior studies ${ }^{7}$ use simultaneous equations to examine the relation between determination of profit and the amount of reinsurance ceded/reinsurance

\footnotetext{
${ }^{2}$ Hancock et al. (2001).

${ }^{3}$ Calandro and Scott (2001).

${ }^{4}$ Cole and McCullough (2006); Adams et al. (2008).

${ }^{5}$ This paper refers to data listed in the Non-life Insurance Review and Insurance Year Books to calculate reinsurance ratios from 1999 to 2009 period in Taiwan and follows the method proposed by Mayers and Smith (1990); Garven and Lamm-Tennant (2003). The reinsurance ratios is (reinsurance ceded) $\div($ direct business written plus reinsurance assumed).

${ }^{6}$ Eling and Luhnen (2010).

${ }^{7}$ Berger et al. (1992).
} 
supply. Unlike their study, we investigate the relationship between reinsurance and firm performance. Specifically, we construct a two-equation structural model and employ a two-stage least squares (2SLS) regression to estimate it.

This paper makes three major contributions to the existing body of literature. First, this study provides new information and some insight that firm performance and reinsurance are interdependent. Second, it fills in the gap in insurance literature regarding the impact of reinsurance and firm performance on each other. Third, it offers managers an integrated thought process for reinsurance decisions and performance management. These findings can serve as a reference for practitioners, academics and competent authorities.

The rest of this paper is organised as follows. The next section locates this research within the literature on reinsurance decisions and insurance firm performance. The subsequent section explains the research methodology and variables development. In the penultimate section, we discuss the results of the empirical study. The final section concludes and discusses the paper.

\section{Literature review}

\section{Effects of firm performance on reinsurance}

Several explanations have been advanced in financial economics literature to explain reinsurance decisions in insurance firms. These include investment incentives, the expected cost of bankruptcy, the hypothesis of risk-bearing and the availability of real services. ${ }^{8}$ Prior research evidence, excluding that of Kader et al., ${ }^{9}$ is consistent with the expected underinvestment hypothesis and the expected cost of bankruptcy argument, that reinsurance purchases are negatively associated with firm performance. Mayers and Smith ${ }^{10}$ suggested that reinsurance purchase may be motivated by an underinvestment problem. Cole and McCullough ${ }^{11}$ further use return on assets (ROA) as a profitability measure to test the underinvestment problem and bankruptcy avoidance as potential motivations for the purchase of reinsurance. They find a negative and significant relationship between ROA and the use of reinsurance. Adams et al. ${ }^{12}$ predict that highly profitable life insurance companies tend to use less reinsurance than less profitable life insurance companies. This is because more profitable life insurance firms are expected to have more cash resources to cover assumed underwriting risks than relatively less profitable life insurance firms. Wang et al. $^{13}$ investigate demutualisation and demand for reinsurance in U.S. propertyliability insurers and find that converting insurers with higher profits decrease overall reinsurance after conversion. They also report that insurers that earn more

\footnotetext{
${ }^{8}$ Mayers and Smith (1990); Hoerger et al. (1990); Adams (1996); Cole and McCullough (2006).

${ }^{9}$ Kader et al. (2010) document significant and positively associated with ROA and life insurer's reinsurance, also show firm performance can affect on reinsurance decision.

${ }^{10}$ Mayers and Smith (1990).

${ }^{11}$ Cole and McCullough (2006).

12 Adams et al. (2008).

${ }^{13}$ Wang et al. (2008).
} 
profits are better able to face losses and financial pressures and thus demand fewer reinsurance contracts.

\section{Effect of reinsurance on insurer's performance}

Reinsurance transactions are related to underwriting risk and capacity, and affect ceding insurers' performance and corporate growth. Previous studies show mixed results concerning the linkage between reinsurance and firm performance. Berger et al. ${ }^{7}$ argue that reinsurance transactions affect primary market profit and show that current profitability is improved by the ceding of reinsurance. Ma and Elango ${ }^{14}$ study internationalisation and the performance of the property-liability insurance industry and find that reinsurance is positively related to firm performance, indicating that firms purchasing more reinsurance experience more stable performance that contributes to higher risk-adjusted returns. Conversely, Choi and Weis ${ }^{15}$ also investigate market structure, efficiency and performance in the U.S. property-liability insurance industry and find that the relationship between profit and reinsurance is unclear; thus, no firm conclusions should be drawn from this study. Shiu ${ }^{16}$ investigates the linkage between insurer performance proxied by investment yield in the U.K. life insurance industry. The empirical results indicate that investment yield is negatively related to reinsurance dependence. In addition, Gatzlaff ${ }^{17}$ further investigates insurer performance and supports a non-linear relationship between reinsurance ceded and performance in his study. $\mathrm{Choi}^{18}$ studies firm growth and size in the U.S. property and liability insurance industry and indicates that insurers using more reinsurance grow slower than those who ceded less or assumed more reinsurance from the primary companies. Thus, Choi and Elyasiani ${ }^{19}$ propose that reinsurance utilisation is negative in revenue efficiency, showing that ceding companies may have to share their profits with the reinsurers, and therefore the revenue side of their operation will be driven down. On the basis of the differences from the above studies, the findings report a positive relationship between reinsurance and performance. Their findings support the notion that reinsurance significantly improves diversification of risk among the policyholder pool, and that reinsurance activities may reduce price, consistent with a view of reinsurance as an alternative to other risk diversification devices. On the other hand, a negative relationship between reinsurance and performance suggests that reinsurance activities may increase costs. Furthermore, when insurers increase reinsurance dependence, it may result in low premium retention levels reducing the potential profitability. We predict that insurers that focus more on stabilising growth and spreading risks through reinsurance contracts would have less profit in this study.

\footnotetext{
${ }^{14} \mathrm{Ma}$ and Elango (2008).

${ }^{15}$ Choi and Weiss (2005).

16 Shiu (2009).

${ }^{17}$ Gatzlaff (2009).

${ }^{18}$ Choi (2010).

${ }^{19}$ Choi and Elyasiani (2011).
} 


\section{Research methodology and variables development}

\section{Data sources}

This study employs an unbalanced sample of the yearly based panel database of the Taiwan property-liability industry. The sample pool consists of data from 15 propertyliability insurers in the period 1999-2009, with a total of 163 data entries. These 15 companies are taken as the research sample, because their share of the propertyliability insurance market adds up to 95 per cent in Taiwan. Hence, the overall sample was representative. During the research period, Tokio Marine Newa Insurance Co., Ltd. was founded in 1999; therefore there was no growth data during that year. In 2009, Walsun Insurance Co., Ltd ceased operations and went out of business; therefore there was no data during that year. Statistics are sourced from the Non-life Insurance Review and Insurance Year Books published by Taiwan Insurance Institute and website materials of the 15 property-liability insurance companies.

\section{Methodology}

This study samples cross-section data of insurance companies and time-series data. Using panel data can help us to avoid the potential problem for omitted time-specific effects, and can provide more informative and robust parameter estimates than timeseries and/or cross-sectional data. Hsiao ${ }^{20}$ suggested that panel data provides a greater sample size and a higher degree of freedom, so as to enhance the efficiency of quantitative model variances.

At the first stage, the parameters are estimated by ordinary least squares (OLS)fixed effects and random effects. However, the equations estimated using OLS ignore the effects in the other direction. ${ }^{21}$ As discussed earlier, an insurer's performance may have an impact on its utilisation of reinsurance and the reinsurance decision also may affect the insurer's operating performance. On the basis of a review of the relevant literature and our arguments of the endogenous nature of an insurance firm's performance and reinsurance decision, in the next stage we extend the analysis of the estimation by using an instrumental variable that accounts for some endogeneity in the explanatory variables, and construct a two-equation simultaneous equation model and estimate it by 2SLS. This model is constructed as follows:

$$
\begin{array}{r}
\text { REINS }_{i t}=\alpha+\beta_{1} F S_{i t}+\beta_{2} I L_{i t}+\beta_{3} F L_{i t}+\beta_{4} R O A_{i t}+\beta_{5} R P_{i t}+\beta_{6} U R_{i t} \\
+\beta_{7} G P_{i t}+\beta_{8} L R_{i t}+\beta_{9} R O I_{i t}+\beta_{10} L B C_{i t}+\beta_{11} F H D_{i t}+\varepsilon_{i t} \\
R O A_{i t}=\alpha+\beta_{1} F S_{i t}+\beta_{2} F L_{i t}+\beta_{3} R_{E I N S_{i t}+\beta_{4} R P_{i t}+\beta_{5} U R_{i t}+\beta_{6} G P_{i t}} \\
+\beta_{7} L R_{i t}+\beta_{8} R O I_{i t}+\beta_{9} M S_{i t}+\beta_{10} L B C_{i t}+\beta_{11} F H D_{i t}+\beta_{12} L D_{i t}+\varepsilon_{i t}
\end{array}
$$

\footnotetext{
${ }^{20}$ Hsiao (1985).

${ }^{21}$ Wooldridge (2006) argues that the explanatory variable is correlated with the error term due to simultaneity, the use of an ordinary least squares (OLS) regression would suffer the simultaneity bias and lead to inconsistency.
} 


\section{Measurement of reinsurance and firm performance variables}

Dependent variables

Reinsurance and firm performance are the dependent variables in Eqs. (1) and (2), respectively. The utilisation of reinsurance, denoted REINS, is measured as the total reinsurance ceded divided by gross premiums written ${ }^{22}$ (stated as a percentage). Hence, this study evaluates performance with financial and accounting indicators. In the earlier studies, $\mathrm{ROA}^{23}$ refers to the proxy variables used to measure the performance of insurers. This study defines ROA as pre-tax income (losses) divided by average assets.

\section{Explanatory variables}

Prior research on reinsurance and firm performance suggests several factors that may affect the dependent variables reinsurance in Eq. (1) and firm performance in Eq. (2). The effects of these factors on the dependent variables are examined as follows, and a list of variables and their definitions are described in Table 1.

\section{Control variables in reinsurance Eq. (1)}

Firm size

Higher default risks lead to stronger demand for reinsurance. ${ }^{24}$ Smaller insurance companies report higher default risks and are more likely to become insolvent. Therefore, they need to narrow the variance of cash flow with reinsurance contracts, in order to enhance their own risk undertaking efficiency. Hence, their demand for reinsurance is high. Prior studies document that reinsurance is negatively related to insurer size. ${ }^{25}$ By referring to Mayers and Smith, ${ }^{10}$ this study measures firm size with natural logarithms of admitted assets.

\section{Insurance leverage}

Insurance companies need to have a sufficient underwriting capacity. Reinsurance can allow insurers to expand their underwriting capacity under the restrictions of the supervisory authorities. Garven and Lamm-Tennant and Cole and $\mathrm{McCullough}^{26}$ predict a positive correlation between direct business written to surplus and demand for reinsurance. Insurers writing more business relative to their surplus should have a higher insolvency probability and therefore experience greater demand for reinsurance. This study refers to Cole and McCullough ${ }^{11}$ by defining insurance leverage as direct business written divided by surplus.

\footnotetext{
${ }^{22}$ Mayers and Smith (1990); Garven and Lamm-Tennant (2003).

${ }^{23}$ Other studies also use ROE or ROA to measure firm performance for example: Browne et al. (2001); Lai and Limpaphayom (2003); Elango et al. (2008); Liebenberg and Sommer (2008).

${ }^{24}$ Lewis and Murdock (1996).

${ }^{25}$ Adams (1996); Garven and Lamm-Tennant (2003); Powell and Sommer (2007).

${ }^{26}$ Garven and Lamm-Tennant (2003); Cole and McCullough (2006).
} 
Table 1 Research variable definitions

\begin{tabular}{|c|c|c|}
\hline $\begin{array}{l}\text { Variable } \\
\text { category }\end{array}$ & Variable names & Definition \\
\hline $\begin{array}{l}\text { Endogenous } \\
\text { variables }\end{array}$ & $\begin{array}{l}\text { Return on assets } \\
\text { Reinsurance }\end{array}$ & $\begin{array}{l}\text { Pre-tax income (losses) / average assets } \\
\text { The ratio of reinsurance premium ceded to direct } \\
\text { business written plus reinsurance assumed }\end{array}$ \\
\hline $\begin{array}{l}\text { Explanatory } \\
\text { variables }\end{array}$ & $\begin{array}{l}\text { Underwriting risk } \\
\text { Growth of premium } \\
\text { Return on investment } \\
\text { Liquidity ratio } \\
\text { Line-of-business } \\
\text { concentration } \\
\text { Market share } \\
\text { Financial holding } \\
\text { Listed dummy }\end{array}$ & $\begin{array}{l}\text { Natural logarithm of admitted assets } \\
\text { Direct business written/surplus } \\
\text { Total liabilities /total assets } \\
\text { (Reinsurance premiums - ceded-reinsurance } \\
\text { commission earned) } \div \text { (claims recovered from reinsurers) } \\
\text { Annual losses incurred (net of loss adjustment expenses) } \\
\text { divided by annual premium earned } \\
\text { Percentage growth in premiums from year } t-1 \text { to year } t \\
\text { Investment income/average invested assets } \\
\text { Stated liabilities/Liquidity assets } \\
\text { Line-of-business Herfindahl index } \\
\text { Ratio of insurer's direct written premiums /total direct } \\
\text { written premiums } \\
\text { Dummy variable equals } 1 \text { if financial holding company; } \\
0 \text { otherwise } \\
\text { Dummy variable equals } 1 \text { if listed company; } 0 \text { otherwise }\end{array}$ \\
\hline
\end{tabular}

\section{Financial leverage}

Studies have found that high leverage is usually linked with rising bankruptcy probability. Garven and Lamm-Tennant ${ }^{27}$ suggested that reinsurance financing is in essence a substitute for the equity of insurers. The lower the holding cost of capital, the higher the financial leverage is. Reinsurance contracts allow insurers and reinsurers to share cost benefits. Given a fixed amount of capital, a high support from premium income means that financial leverage can be reduced. Garneiro and Sherris ${ }^{28}$ found strong evidence of a positive relationship between financial leverage and the demand for reinsurance. This study refers to Powell and Sommer ${ }^{29}$ by using the ratio of total liabilities to total assets to assess financial leverage.

\section{Underwriting risk}

The motivation for purchasing reinsurance is due to risk-bearing which holds that reinsurance is motivated by the ability of residual claimants to effectively hedge against operational risk. Reinsurance improves the predictability of cash flow and

\footnotetext{
${ }^{27}$ Garven and Lamm-Tennant (2003).

${ }^{28}$ Garneiro and Sherris (2009).

${ }^{29}$ Powell and Sommer (2007).
} 
474

lowers the volatility of earnings. Hoerger at al. ${ }^{30}$ show that a positive relationship exists between the level of risk by line of insurance and the demand for reinsurance. This study refers to Adams and Buckle ${ }^{31}$ and measured underwriting risk by the loss ratio (annual losses incurred divided by annual premium earned).

\section{Line-of-business concentration}

According to the real service hypothesis, insurance companies with a lower concentration in business lines may require more reinsurance. They issue policies for multiple lines of business and have an incentive to purchase reinsurance so as to obtain more reinsurance services. On the other hand, reinsurance contracts are a risk diversification mechanism for insurance companies. To diversify risks, a higher concentration in specific lines means a strong demand for reinsurance. Therefore, according to these conflicting expectations, the influence of business concentration is ambiguous in the existing literature. We use a line-of-business Herfindahl index to proxy line-of-business concentration.

\section{Reinsurance price}

According to the underwriting capacity limitation theory, heavy losses will restrict the overall supply of reinsurance and enhance reinsurance prices. ${ }^{32}$ This will in turn result in a decline in reinsurance demand. Cole and $\mathrm{McCullough}^{11}$ examined reinsurance market factors with reinsurance prices and explored the influence of reinsurance prices on reinsurance demands. The results suggest that there is a negative correlation between reinsurance costs and reinsurance demand. However, owing to data unavailability, we measure reinsurance price as reinsurance premiums ceded minus reinsurance commission earned divided by claims recovered from reinsurers.

\section{Growth of premium}

Webb et al. ${ }^{33}$ argued that under statutory accounting rules, the more rapid the growth in premiums, the greater the burden is to capitalisation. Reinsurance can effectively ease such a burden and reduce the pressure for capital injection as a result of business growth. Hence, there is a correlation between premium growth and reinsurance demands. This study referred to Sharpe and Standnick ${ }^{34}$ and measured premium growth as percentage growth in premiums from year $t-1$ to year $t$.

\section{Liquidity ratio}

Lee and Urrutia $^{35}$ found that the current liquidity ratio is a significant indicator of solvency. The insurer with more liquid assets would be relatively unlikely to expose

\footnotetext{
${ }^{30}$ Hoerger et al. (1990).

31 Adams and Buckle (2003).

${ }^{32}$ Weiss and Chung (2004).

${ }^{33}$ Webb et al. (1992).

${ }^{34}$ Sharpe and Standnick (2007).

${ }^{35}$ Lee and Urrutia (1996).
} 
itself to liquidity risk than would an insurer with less. Therefore, if the insurer is liquid, or has a sufficient amount of cash and invested assets on hand, insurers will likely consider the industry more stable and financially sound and reinsure less. This study refers to Chen and Wong ${ }^{36}$ who use an inverse measure of the liquidity ratio variable, that is stated liabilities divided by liquid assets to measure liquidity.

\section{Return on investment}

Graven and Lamm-Tennant ${ }^{27}$ found that high leverage, low return on investment (ROI) and claim costs lead to high demands for reinsurance. This shows that investment returns have an impact on reinsurance decisions. This study refers to Chen and Wong ${ }^{36}$ to evaluate ROI as investment income divided by average invested assets.

\section{Financial holdings}

Conglomerates or similar organisations are usually deemed as an important factor when regarding reinsurance purchases. Mayers and $\mathrm{Smith}^{10}$ assumed that if an insurance company is a member of a group, it is expected to report a strong demand for reinsurance. For affiliates of the same group, reinsurance can transfer income within the group and ultimately lower the tax burden of the entire group. If a sampled company is a subsidiary of a financial-holding group, the dummy variable is defined as 1 . If it is otherwise, the dummy variable is 0 .

\section{Control variables in performance Eq. (2)}

Firm size

Hardwick $^{37}$ argued that large insurance companies outperform smaller counterparts, because they can achieve operational cost efficiency through increasing output and streamlining the workflow. The majority of studies support that there is a positive correlation between company size and firm performance. ${ }^{38}$ However, the empirical study by Lai and Limpaphayom ${ }^{39}$ found that there is a negative correlation between company size and profitability in the insurance industry. Therefore, the correlation between company size and firm performance is ambiguous.

\section{Underwriting risk}

Insurers that undertake risky business and the diversification of underwriting risks help to mitigate exposure to underwriting losses ex ante and improve operational profits. Lower anticipated losses may lead to better performance because the monitoring and claims handling costs are low.

\footnotetext{
${ }^{36}$ Chen and Wong (2004).

${ }^{37}$ Hardwick (1997).

${ }^{38}$ Cummins and Nini (2002); Liebenberg and Sommer (2008).

${ }^{39}$ Lai and Limpaphayom (2003).
} 


\section{Growth of premium}

The higher the growth, the more aggressive the company's strategy is. This could have an impact on performance. The literature suggests that premium growth is an indicator of insolvency. Kim et al. $^{40}$ found that there is a significantly positive correlation between premium growth and insolvency of property-liability insurance companies. However, this does not mean that a lower premium growth results in good performance. There might well be an optimal growth rate and firms either above or below the optimum rate would be at a competitive disadvantage.

\section{Liquidity ratio}

Liquidity measures the ability of managers in insurance to fulfil their immediate commitments to policyholders and other creditors without having to increase profits from underwriting and investment activities and/or liquidate financial assets. This reasoning therefore implies that high liquidity obviates the need for management to improve annual financial performance. It is therefore expected that insurance companies with more liquid assets will outperform those with less liquid assets. Browne et ll $^{41}$ provide evidence supporting that performance is positively related to the proportion of liquid assets in the asset mix of an insurance company.

\section{Return on investment}

Investment is another construct to the measurement of the performance of propertyliability insurance companies. The collection and investment of insurance premiums take place before the payment for insurance claims. Good investment returns can generate competitive advantages, particularly in situations where investments matter more than underwriting profits/losses. All else being equal, high investment returns result in a better financial performance for insurance companies. Gatzlaff ${ }^{17}$ provides evidence supporting that ROI is positively and significantly related to firm performance (ROA and ROE).

\section{Line-of-business concentration}

A high concentration of business lines helps to mitigate pricing competition as there is better efficiency compared to other insurers. ${ }^{42}$ For property-liability insurance companies, a high concentration of business lines means professional operations and accurate predictions of potential losses. ${ }^{43}$ This helps to create profitability forecasts. However, a high concentration of business lines means that potentially high risks may impact performance.

\footnotetext{
${ }^{40}$ Kim et al. (1995).

41 Browne et al. (2001).

${ }^{42}$ Chidambaran et al. (1997).

${ }^{43}$ Mayers and Smith (1988).
} 
Reinsurance price

Cummins et $a l .{ }^{44}$ performed an empirical analysis on the cost and benefit of reinsurance and found that insurance companies are willing to pay high prices to purchase reinsurance in order to reduce underwriting risks. This shows that there is a trade-off between reinsurance costs and risk undertaking. However, according to the empirical study by Shiu $^{16}$ on the relationship between investment returns and reinsurance purchased by life insurance companies in the U.K., there is a negative correlation between reinsurance utilisation and investment gains. As reinsurance purchases are subject to cost factors, this study includes reinsurance prices as an indicator.

\section{Financial leverage}

Although leverage brings about lower operational costs, it also enhances the possibility of financial distress. ${ }^{45}$ The cash flow hypothesis proposed by Jensen ${ }^{46}$ suggested that high financial leverage can enhance financial performance because it forces managers to generate cash flow to meet obligations to creditors. Adams and Buckle's ${ }^{31}$ empirical study on insurance markets supports the cash flow hypothesis.

\section{Market share}

Industrial organisation economists proposed that market structure impacts firm behaviour and hence influences performance. Numerous studies found a positive statistical relationship between industry concentration and firm profitability. ${ }^{47}$ Firms with a large market share are able to exercise market power in pricing products and earn higher profits. Thus, market share is expected to have a positive relationship with firm performance. This study refers to Choi and Weiss ${ }^{15}$ by using the ratio of insurer's direct written premiums divided by total direct written premiums to measure market share.

\section{Financial holdings}

Financial-holding groups are growing in dominance in the financial industry. An insurer who is part of a large group will be able to pool and share resources with other members, thereby gaining higher efficiency in operations through better utilisation of resources. (e.g. co-marketing and channel sharing). ${ }^{48}$ Hence, this study refers to financial-holding structures as a variable to establish the relationship with firm performance.

\footnotetext{
${ }^{44}$ Cummins et al. (2008).

45 Colquitt and Hoyt (1997).

46 Jensen (1986).

${ }^{47}$ Berger (1995); Choi and Weiss (2005).

${ }^{48}$ Colquitt et al. (1999).
} 


\section{Listed dummy}

Monitoring and scrutiny by shareholder and analysts implies a more effective market for corporate control for listed insurers than is present for private insurers, Hence, we expect that listed insurers should have better performance. We use a dummy variable to observe the correlation between listing and firm performance. When a propertyliability insurance company is listed, it is classified as 1 and 0 otherwise.

\section{Empirical results}

\section{Descriptive statistical analysis of variables}

Table 2 presents the basic statistics of the dependent variables and explanatory variables, as well as variance inflation factors (VIF). Reinsurance has a mean of 0.4679 and a standard deviation of 0.1243 , whereas ROA has a mean of 0.0186 and a standard deviation of 0.0548 . The mean value of the reinsurance ratio is higher than the reported mean of 0.3512 in the U.S property-liability insurance industry; ${ }^{18}$ this shows that Taiwan's property-liability market is more dependent on the use of reinsurance. However, ROA is relatively low. The property-liability insurance industry is faced with pressure from the shareholders. Their profits are limited; therefore, firm performance is critical.

In untabulated results of the Pearson correlation coefficient matrix, we find that consistent with our expectations, reinsurance is negatively correlated with the ROA with a correlation coefficient of -0.175 , statistically significant at the 0.025 level. Overall, the absolute values for the correlation coefficients between pairs of explanatory variables are generally modest. We also calculate the VIF values for each explanatory variable. According to Gujarati, ${ }^{49}$ multicollinearity is not considered

Table 2 Descriptive statistics of variables and variance inflation factors (VIF)

\begin{tabular}{|c|c|c|c|c|c|c|}
\hline Variable & Mean & Std. dev. & Min & $\operatorname{Max}$ & $\begin{array}{c}V I F \\
E q .(1)\end{array}$ & $\begin{array}{c}V I F \\
E q .(2)\end{array}$ \\
\hline Return of assets & 0.0186 & 0.0548 & -0.300 & 0.350 & 1.42 & - \\
\hline Reinsurance & 0.4679 & 0.1243 & 0.19 & 0.80 & - & 1.72 \\
\hline Firm size & 16.031 & 1.4378 & 11.15 & 20.46 & 1.53 & 2.39 \\
\hline Insurance leverage & 1.6001 & 5.5221 & -63.28 & 18.42 & 1.13 & - \\
\hline Financial leverage & 0.6788 & 0.1804 & 0.210 & 1.420 & 2.75 & 2.75 \\
\hline Reinsurance price & 2.2761 & 4.9630 & -17.63 & 55.90 & 1.18 & 1.19 \\
\hline Underwriting risk & 0.5546 & 0.1713 & 0.140 & 1.290 & 1.35 & 1.32 \\
\hline Growth of premium & 0.0393 & 0.1495 & -0.500 & 0.900 & 1.05 & 1.08 \\
\hline Return on investment & 0.0266 & 0.0250 & -0.082 & 0.161 & 1.15 & 1.10 \\
\hline Liquidity ratio & 1.1364 & 0.3938 & 0.310 & 2.620 & 2.60 & 2.98 \\
\hline Line-of-business concentration & 0.3356 & 0.1294 & 0.157 & 0.921 & 1.14 & 1.72 \\
\hline Market share & 0.0639 & 0.0532 & 0.0002 & 0.442 & - & 1.10 \\
\hline Financial holding dummy & 0.2622 & 0.4412 & 0.000 & 1.000 & 1.18 & 1.46 \\
\hline Listed dummy & 0.5549 & 0.4985 & 0.000 & 1.000 & - & 1.88 \\
\hline
\end{tabular}

\footnotetext{
${ }^{49}$ Gujarati (1995).
} 
a severe problem if the VIF value is less than 10. All the VIF values of the explanatory variables are smaller than 3 , and Table 2 lists the VIF value, suggesting that problems associated with multicollinearity are relatively unlikely in our analysis.

\section{Optimum panel data model}

An examination of the VIF, residual plot and normality plot reveals no serious violations of regression assumptions such as multicollinearity and heteroscedasticity. Because our data is integrated cross-sectional and time-series panel data, we apply a 2SLS regression for the panel data model. First, we must consider the optimal model. The $F$-test is adopted to verify the selection of the fixed effects model and the OLS model. The verification results show that models 1 and 2 reject the null hypothesis. Accordingly, this demonstrates that the fixed effects model is superior to the OLS method. Furthermore, the Lagrange Multiplier (LM) test is employed to conduct a verification of the choice of the random effects model and the OLS method. The verification results show that models 1 and 2 reject the null hypothesis, and thus verify that the random effects model is superior to the OLS method.

Both the $F$-test and LM test results reveal that the fixed effects model and the random effects model have a greater applicability than the OLS method. The Hausman test is further adopted to test the selection between the fixed effects method and the random effects method. The results show that models 1 and 2 do not reject the null hypothesis. Accordingly, models 1 and 2 adopt the random effects model as the basis for the empirical analysis. The results of the optimum panel data model are summarised as Table 3.

An empirical study is conducted based on 2SLS regression models for panel data in order to examine reinsurance and performance. For expositional convenience, we first report the results for Eq. (1), followed by those for Eq. (2).

\section{Effect of performance on reinsurance result for Eq. (1)}

Table 4 shows the results for Eq. (1) $F$-tests for the overall statistical goodness of fit of the 2SLS model are significant at the 0.01 level. The adjusted $R^{2}$ for the model is 0.4306 . The models show the ROA has significantly negative effects on reinsurance purchases at the 0.045 level, which supports the view that insurers with the higher ROA tend to purchase less reinsurance. This evidence is consistent with the underinvestment hypothesis. Our finding is in line with that of Mayers and Smith,

Table 3 Optimum panel data model

\begin{tabular}{|c|c|c|}
\hline & Eq. (1) (reinsurance decision) & Eq. (2) (firm performance) \\
\hline$F$-test & $4.99 * * *$ & $3.55 * * *$ \\
\hline LM test & $114.20 * * *$ & $69.22 * * *$ \\
\hline Hausman test & 14.42 & 1.29 \\
\hline
\end{tabular}

Notes: *Significant at 0.10 level; **significant at 0.05 level;*** significant at 0.01 level. 
Table 4 Effect of performance on reinsurance

\begin{tabular}{lcccc}
\hline Dependent variable & \multicolumn{2}{c}{ Reinsurance decisions } \\
\cline { 2 - 5 } & $\begin{array}{c}\text { Expected } \\
\text { sign }\end{array}$ & Coefficient & z-value & p-value \\
\cline { 2 - 5 } & & 0.74054 & 7.49 & $0.000^{* * *}$ \\
\hline Intercept & & -0.33289 & -2.0 & $0.045^{* *}$ \\
Return on assets & - & -0.00065 & -0.10 & 0.921 \\
Firm size & - & 0.00001 & 0.01 & 0.994 \\
Insurance leverage & + & 0.02825 & 0.40 & 0.688 \\
Financial leverage & + & 0.00154 & 0.92 & 0.356 \\
Reinsurance price & - & 0.10335 & 1.98 & $0.048^{* *}$ \\
Underwriting risk & + & 0.07723 & 1.47 & 0.141 \\
Growth of premium & + & -0.11604 & -3.69 & $0.000^{* * *}$ \\
Liquidity ratio & + & -0.70131 & -2.15 & $0.032^{* * *}$ \\
Return on investment & - & 0.52755 & -7.86 & $0.000^{* * *}$ \\
Line-of-business concentration & - & -0.04850 & -2.58 & $0.010^{* * *}$ \\
Financial holding & $+/-$ & 0.4306 & & $114.20 * * *$ \\
Adjusted $R^{2}$ & & &
\end{tabular}

The definitions of the variables can be found in Table $1 .{ }^{*}$ significant at 0.10 level; **significant at 0.05 level; ***significant at 0.01 level.

Notes: The dependent variable for specifications above is reinsurance. $F S=$ Firm size; $I L=$ Insurance leverage; $F L=$ Financial leverage; $R O A=$ Return on assets; $R P=$ Reinsurance price; $U R=$ Underwriting risk; $G P=$ Growth of premium; $L R=$ Liquidity ratio; $R O I=$ Return on investment; $L B C=$ Line-of-business concentration; $F H D=$ Financial holding dummy variable equals 1 if financial holding company; 0 otherwise

Cole and McCullough and Adams et al..$^{50}$ who find strong support for the prediction that more profitable insurers tend to reinsure less than profitable insurers. This result supports the theory that reinsurance is used to combat the underinvestment problem by reducing the likelihood that managers will reject positive net present value projects due to the existence of possible large unexpected losses.

In the 2SLS model, the coefficients of line-of-business concentration are negative and highly significant. This result is consistent with the empirical findings of Cole and McCullough ${ }^{11}$ and supports the real service hypothesis, suggesting that the more focused the insurer is relative to line of business concentration, the less reinsurance it will demand. The significantly negative coefficients on the liquidity ratio variable in the model do not support the proposition that the insurer has sufficient liquidity assets to consider reducing the demand for reinsurance.

In line with Adams, ${ }^{51}$ we find that the underwriting risk variables are positive and significant in the model, suggesting that insurers with a greater underwriting risk are more likely to purchase higher amounts of reinsurance. This is consistent with the risk-bearing hypothesis, which postulates that insurers with high underwriting risk

\footnotetext{
${ }^{50}$ Mayers and Smith (1990); Cole and McCullough (2006); Adams et al. (2008).

51 Adams (1996).
} 
are likely to reinsure to a greater extent than firms writing less risky lines of insurance to effectively hedge against operational risk. The ROI variables are negative and statistically significant in the 2SLS model. The finding is consistent with the view of Graven and Lamm-Tennant ${ }^{27}$ that low ROI leads to high demands for reinsurance. The financial holding dummy variables are negative and significant in the model, suggesting that financial holding insurance companies have a wide source of capital and hence low reinsurance.

\section{Effect of reinsurance on firm performance result for Eq. (2)}

Table 5 shows the results for Eq. (2) $F$-tests for the overall statistical goodness of fit of the 2SLS model is significant at the 0.01 level. The adjusted $R^{2}$ for the model is 0.3518 . As expected, reinsurance has statistically significantly negative effects on firm performance in the model at the 0.042 level. This finding is consistent with the view that insurers with higher reinsurance dependence tend to have a lower level of firm performance. This is possibly because insurers with low retention limits act as if they were the brokers of reinsurers because a high proportion of their premiums have to be handed over to reinsurers and may affect firm performance. Our findings are

Table 5 Effect of reinsurance on firm performance

\begin{tabular}{|c|c|c|c|c|}
\hline \multirow[t]{3}{*}{ Dependent variable } & \multicolumn{4}{|c|}{ Return on assets } \\
\hline & \multirow{2}{*}{$\begin{array}{l}\text { Expected } \\
\text { sign }\end{array}$} & \multicolumn{3}{|c|}{$2 S L S$} \\
\hline & & Coefficient & $z$-value & p-value \\
\hline Intercept & & -0.09252 & -1.48 & 0.138 \\
\hline Reinsurance & - & -0.07936 & -2.03 & $0.042 * *$ \\
\hline Firm size & $+/-$ & 0.01677 & 4.22 & $0.000 * * *$ \\
\hline Financial leverage & - & -0.07044 & -2.07 & $0.039 * *$ \\
\hline Reinsurance price & - & 0.00034 & 0.42 & 0.671 \\
\hline Underwriting risk & - & -0.06643 & -2.66 & $0.008 * *$ \\
\hline Growth of premium & $+/-$ & 0.02495 & 0.97 & 0.332 \\
\hline Liquidity ratio & - & -0.03280 & -2.01 & $0.044 * *$ \\
\hline Return on investment & + & 0.34007 & 2.20 & $0.028 * *$ \\
\hline Market share & + & -0.04889 & -0.53 & 0.598 \\
\hline Line-of-business concentration & + & -0.00536 & -0.13 & 0.893 \\
\hline Financial holding & $+1-$ & -0.00504 & -0.50 & 0.619 \\
\hline Listed dummy & $+1-$ & -0.00571 & -0.56 & 0.575 \\
\hline Adjusted $\mathrm{R}^{2}$ & \multicolumn{4}{|c|}{0.3158} \\
\hline$F$-value & \multicolumn{4}{|c|}{$62.76^{* * *}$} \\
\hline
\end{tabular}

The definitions of the variables can be found in Table 1 . ${ }^{*}$ Significant at 0.10 level; ** significant at 0.05 level; *** significant at 0.01 level.

Notes: The dependent variable for specifications above is return on assets. $F S=$ Firm size; FL $=$ Financial leverage; $R E I N S=$ Reinsurance; $R P=$ Reinsurance price; $U R=$ Underwriting risk; $G P=$ Growth of premium; $L R=$ Liquidity ratio; $R O I=$ Return on investment; $M S=$ Market share; $L B C=$ Line-of-business concentration; $F H D=$ Financial holding dummy variable equals 1 if financial holding company; 0 otherwise; $L D=$ listed dummy variable equals 1 if listed company; 0 otherwise. 
similar to the results of Choi, ${ }^{18}$ who find that primary insurers, which cede more reinsurance, may have a steady flow of profits at the expense of slow growth.

Turning to the control variables, the firm size variables are positive and statistically significant at the 0.01 level in the 2SLS model. This evidence supports the view of Cummins and $\mathrm{Zi}^{52}$ who reported that large insurers have higher operational efficiencies. The significantly positive coefficients on the ROI variable in the model support the proposition that insurers with higher investment returns have better financial performance. We find that the coefficients for the underwriting risk variable are negative and highly significant in the model. This suggests that a higher underwriting risk means a low ROA consistent with Elango et al., ${ }^{53}$ showing that insurers that underwrite risky business (e.g. risks associated with catastrophe coverage) require good management standards in order to mitigate their exposure to underwriting losses ex ante and maximise returns on invested assets ex post. Managers are encouraged to increase cash flow by undertaking risks in a cautious manner so as to improve financial performance.

The financial leverage and liquidity variables are negative and statistically significant in the 2SLS model. These findings are consistent with the view that higher levels of financial risk would likely be reflected in low market value for the firm.

\section{Conclusions and discussion}

This article has investigated the effects of firm performance on reinsurance decisions and the reverse causality between reinsurance on firm performance using panel data on Taiwan property-liability insurers from 1999 to 2009. Consistent with the expected underinvestment hypothesis, bankruptcy costs argument and the risk-bearing hypothesis, insurers that are more profitable should be better able to absorb large unexpected losses and therefore be less affected by the underinvestment problem. Moreover, we document the reverse causality from reinsurance to firm performance. We find that insurers purchasing more reinsurance would have low firm performance. This result supports the view that insurers with a high retention level outperform those with a low retention level. This may be because there is a cost for reinsurance. The ceding company has to pay a proportional share of the premium collected to the reinsurer. If the retention is low, then the insurer's capital and surplus cannot be put to effective use because low retention means low underwriting profits and investment income. Taken together, our evidence suggests that performance negatively affects reinsurance, and vice versa. To sum up, we have argued that insurers with higher ROA tend to purchase less reinsurance and insurers with higher reinsurance dependence tend to have a lower level of firm performance.

We consider that our research findings on management of the insurance industry have an important implication. The results of this investigation offer some insight that firm performance and reinsurance are interdependent. Prior research ${ }^{54}$ concludes that insurers

\footnotetext{
${ }^{52}$ Cummins and Zi (1998).

53 Elango et al. (2008).

${ }^{54}$ Mayers and Smith (1990); Adiel (1996); Shortridge and Avila (2004).
} 
with a higher likelihood of insolvency purchase more reinsurance. Hence, managers have to strike a balance between decreasing insolvency risk and reducing potential profitability.

\section{References}

Adams, M. (1996) 'The reinsurance decision in life insurance firms: An empirical test risk-bearing hypothesis', Accounting and Finance 36: 15-30.

Adams, M. and Buckle, M. (2003) 'The determinants of corporate financial performance in the Bermuda insurance market', Applied Financial Economics 13: 133-143.

Adams, M., Hardwick, P. and Zou, H. (2008) 'Reinsurance and corporate taxation in the United Kingdom life insurance industry', Journal of Banking and Finance 32(1): 101-115.

Adiel, R. (1996) 'Reinsurance and the management of regulatory ratios and taxes in the property-casualty insurance industry', Journal of Accounting and Economics 22: 207-240.

Berger, L.A. (1995) 'The profit-structure relationship in banking: Test of market-power and efficientstructure hypotheses', Journal of Money Credit and Banking 27: 401-431.

Berger, L.A., Cummins, J.D. and Tennyson, S. (1992) 'Reinsurance and the liability insurance crisis', Journal of Risk and Uncertainty 5: 253-272.

Browne, M.J., Carson, J.M. and Hoyt, R.E. (2001) 'Dynamic financial models of life insurers', North American Actuarial Journal 5: 11-26.

Calandro, J.J. and Scott, L. (2001) 'The Insurance Performance Measure (IPM): Bringing value to the insurance industry', Journal of Applied Corporate Finance 14(4): 8-13.

Chen, R. and Wong, K.A. (2004) 'The determinants of financial health of Asian insurance companies', Journal of Risk and Insurance 71(3): 469-499.

Chidambaran, N.K., Pugel, T.A. and Saunders, A. (1997) 'An investigation of the performance of the U.S. property-liability insurance industry', Journal of Risk and Insurance 64(2): 371-381.

Choi, B.P. (2010) 'The U.S. property and liability insurance industry: Firm growth, size, and age', Risk Management and Insurance Review 13(2): 207-224.

Choi, B.P. and Elyasiani, E. (2011) 'Foreign-owned insurance performance in the US property-liability markets', Applied Economics 43(3): 291-306.

Choi, B.P and Weiss, M.A. (2005) 'An empirical investigation of market structure, efficiency, and performance in property-liability insurance', Journal of Risk and Insurance 72(4): 635-673.

Cole, C.R. and McCullough, K.A. (2006) 'A reexamination of the corporate demand for reinsurance', Journal of Risk and Insurance 73(1): 169-192.

Colquitt, L.L. and Hoyt, R.E. (1997) 'Determinants of corporate hedging behavior: Evidence from the life insurance industry', Journal of Risk and Insurance 64(4): 649-671.

Colquitt, L.L., Sommer, D.W. and Godwin, N.H. (1999) 'Determinants of cash holding by property-liability insurers', Journal of Risk and Insurance 66(4): 401-415.

Cummins, J.D., Dionne, G., Gagné, R. and Nouira, A. (2008) 'The costs and benefits of reinsurance', SCOR/JRI conference.

Cummins, J.D. and Nini, G.P. (2002) 'Optimal capital utilization by financial firms: Evidence from the property-liability insurance industry', Journal of Financial Services Research 21(1/2): 15-53.

Cummins, J.D. and Zi, H. (1998) 'Comparison of frontier efficiency methods: An application to the U.S. life insurance industry', Journal of Productivity Analysis 10(2): 131-152.

Elango, B., Ma, Y. and Pope, N. (2008) 'An investigation into the diversification -performance relationship in the U.S. property-liability insurance industry', Journal of Risk and Insurance 75(3): 567-591.

Eling, M. and Luhnen, M. (2010) 'Frontier efficiency methodologies to measure performance in the insurance industry: Overview, systematization, and recent developments', The Geneva Papers on Risk and Insurance-Issues and Practice 35: 217-265.

Garneiro, L.A. and Sherris, M. (2009) 'Demand for reinsurance: Evidence from Australian insurers', ChinaUSA Business Review 8(10): 1-21.

Garven, J.R. and Lamm-Tennant, J. (2003) 'The demand for reinsurance: Theory and empirical test', Assurance 71: 217-238.

Gatzlaff, K. (2009) Dimensions of property-liability insurer performance, Florida State University doctoral dissertation. 
Gujarati, D.N. (1995) Basic Econometrics, New York: McGraw Hill.

Hancock, J., Huber, P. and Koch, P. (2001) 'Value creation in the insurance industry', Risk Management and Insurance Review 4(2): 1-9.

Hardwick, P. (1997) 'Measuring cost inefficiency in the UK life insurance industry', Applied Financial Economics 7: 37-44.

Hoerger, T.J., Sloan, F.A. and Hassan, M. (1990) 'Loss volatility, bankruptcy, and the demand for reinsurance', Journal of Risk and Uncertainty 3: 221-245.

Hsiao, C. (1985) 'Benefits and limitations of panel data', Econometric Reviews 4(1): 121-174.

Jensen, M.C. (1986) 'Agency costs of free cash flow, corporate finance and takeover', American Economic Review: Papers and Proceedings 76: 323-329.

Kader, H.A., Adams, M. and Mouratidis, K. (2010) 'Testing for trade-offs in the reinsurance decision of United Kingdom life insurance firms', Journal of Accounting, Auditing \& Finance 25(3): 491-522.

Kim, Y.-D., Anderson, D.R., Amburguey, T.L. and Hickman, J.C. (1995) 'The use of event history analysis to examine insurer insolvencies', Journal of Risk and Insurance 62(1): 94-110.

Lai, G.C. and Limpaphayom, P. (2003) 'Organizational structure and performance: Evidence from the Nonlife Insurance Industry in Japan', Journal of Risk and Insurance 70(4): 735-757.

Lee, S.H. and Urrutia, J.L. (1996) 'Analysis and prediction of insolvency in the property-liability insurance industry: A comparison of logit and hazard models', Journal of Risk and Insurance 63(1): 121-130.

Lewis, C.M. and Murdock, K.C. (1996) 'The role of government contracts in discretionary reinsurance markets for natural disasters', Journal of Risk and Insurance 63(4): 567-597.

Liebenberg, A.P. and Sommer, D.W. (2008) 'Effects of corporate diversification: Evidence from the property-liability insurance industry', Journal of Risk and Insurance 75(4): 893-919.

Ma, Y. and Elango, B. (2008) 'When do international operations lead to improved performance? An analysis of property-liability insurer', Risk Management and Insurance Reviews 11(1): 141-155.

Mayers, D. and Smith, C.W. (1990) 'On the corporate demand for insurance: Evidence from the reinsurance market', Journal of Business 63: 19-40.

Mayers, D. and Smith, C.W. (1988) 'Ownership structure across lines of property-casualty insurance', Journal of Law and Economics 26: 1-23.

Powell, L.S. and Sommer, D.W. (2007) 'Internal versus external capital markets in the insurance industry: The role of reinsurance', Journal of Financial Service Research 31: 173-188.

Sharpe, I.G. and Standnick, A. (2007) 'Financial distress in Australian general insurers', Journal of Risk and Insurance 74(2): 377-399.

Shiu, Y. (2009) 'Economic factors, firm characteristics and performance: A panel data analysis for United Kingdom life offices', Applied Economics Letters 16: 1033-1037.

Shortridge, R.T. and Avila, S.M. (2004) 'The impact of institutional ownership on the reinsurance decision', Risk Management and Insurance Review 7(2): 93-106.

Wang, J.L., Chang, V.Y., Lai, G.C. and Tzeng, L.Y. (2008) 'Demutualization and demand for reinsurance', The Geneva Papers on Risk and Insurance-Issues and Practice 33(3): 566-584.

Webb, B.L., Harrison, C.M. and Markham, J.J. (1992) Insurance Operations, Malvern Pennsylvania: American Institute for Chartered Casualty Underwriters.

Weiss, M.A. and Chung, J. (2004) 'Reinsurance prices, financial quality, and global capacity', Journal of Risk and Insurance 71(3): 437-467.

Wooldridge, J.M. (2006) Introductory Econometrics: A Modern Approach, 3rd edn, Cincinnati, OH: SouthWestern.

\section{About the Authors}

Hsu-Hua Lee is Associate Professor in Graduate Institute of Management Sciences at Tamkang University in Taiwan.

Chen-Ying Lee is a Ph.D. Student in Graduate Institute of Management Sciences at Tamkang University in Taiwan. 